2 Murbarak SJ, Owen CA. Compartmental syndrome and its relation to the crush syndrome. Clin Orthop 1975;113:81-9.

Owen CA, Mubarak SJ, Hargens AR, et al. Intramuscular pressures with limb compression, N Englf Med 1979;300:1169-72.

4 Ron D, Taitelman U, Michaelson M, Bar-Joseph C, Bursztein S, Better OS. Prevention of acute renal failure in traumatic rhabdomyolysis. Arch Intern Med 1984;144:277-80.

5 Rommel FM, Kabler RM, Mowad JJ. The crush syndrome: a complication of urological surgery. f Urol 1986;135:809-11.

6 Maull KI, Capehart JE, Cardea JA, Haynes BW. Limb loss following military anti-shock trousers (MAST) application. $\mathcal{J}$ Trauma 1981;21:60-2.

7 Matsen FA, Kragmire RB. Compartmental syndromes. Surg Gynecol Obstet 1878;147:943-7.

8 Robbs JV, Baker LW. Late revascularisation of the lower limb following acute arterial occlusion. Brf Surg 1979;66:129-31.

9 Bywaters EGL, Beall D. Crush injuries with impairment of renal function. Br Med $\mathcal{F} 1941$;i: $427-32$.

10 Members of the medical staff of three London hospitals. Moorgate tube train disaster. II. Clinicopathological review. BrMed $\mathcal{f} 1975$;iii:729-31.

11 Brown AA, Nichols RJ. Crush syndrome: a report of 2 cases and a review of the literature. $\mathrm{Br} \mathcal{f}$ Surg 1977;64:397-402.

2 Jones RN. Crush syndrome in a Cornish tin miner. Injury 1983;15:282-3.

13 Gabow PA, Kaehny WD, Kelleher SP. The spectrum of rhabdomyolysis. Medicine 1982;62: $141-52$.

14 Allister C. Cardiac arrest after crush injury. Br Med $\mathcal{F}$ 1983;287:531-2.

15 Stewart RJ, Young JC, Kenney DA, Hirschbert JM. Field surgical intervention: an unusual case. F Trauma 1979;19:780-3.

16 Eneas JF, Schoenfeld PY, Humphreys MH. The effect of infusion of mannitol-sodium bicarbonate on the clinical course of myoglobinuria. Arch Intern Med 1979;139:801-5.

17 Weeks RS. The crush syndrome. Surg Gynecol Obstet 1968;127:369-75.

18 Anonymous. Crush injuries [Editorial]. Br Med f 1977; ii:1244.

\section{Collagenous colitis: disease or diversion?}

Unexplained chronic diarrhoea is common, and in 1976 a distinctive histological change of the large intestinal mucosa termed "collagenous colitis" was proposed by Lindstrom as a cause of chronic watery diarrhoea. ${ }^{1}$ Ten years later more than 50 cases have been described. ${ }^{1.15}$ The histological hallmark of collagenous colitis is a thick eosinophilic band in the superficial aspect of the colonic mucosa, immediately deep to the surface epithelium and sometimes extending around the uppermost part of the crypts. Examination by histochemistry, ${ }^{23}$ electron microscopy, ${ }^{31416}{ }^{17}$ and immunocytochemistry ${ }^{98}$ has confirmed that the band is collagenous and has shown that there may be subtle changes in the adjacent epithelium, capillary endothelium, and pericryptal fibroblasts. ${ }^{14} 17$ Subepithelial collagen in the colonic mucosa is not in itself pathological (its synthesis is a physiological function of the pericryptal fibroblast sheath related to epithelial cell turnover ${ }^{192}$ ), but it is usually inconspicuous on routine examination by light microscopy. ${ }^{21}$ Most studies of its thickness in "control" samples show that the upper limit of normal can be taken as $7 \mu \mathrm{m},{ }^{359112223}$ whereas in collagenous colitis it usually exceeds $15 \mu \mathrm{m}$ and in many cases reaches $60-70 \mu \mathrm{m}$. $^{1-15}$

The cause of the excessive collagen deposition is a mystery. Although the term collagenous colitis trips easily off the tongue, the colitis is often unimpressive on histological examination. In most cases inflammatory cells, usually lymphocytes and plasma cells, ${ }^{6}$ are only modestly increased in the mucosa, but sometimes eosinophils ${ }^{7}$ or mast cells ${ }^{9}$ are conspicuous. Nevertheless, the changes of collagenous colitis have occasionally followed a histologically proved acute, but non-specific, mucosal inflammation. ${ }^{1012} \mathrm{~A}$ thickened collagen plate is not a feature of ulcerative colitis, Crohn's disease, or any hitherto recognised variety of inflammatory bowel disease..$^{594}$

Collagenous colitis occurs almost exclusively in women, and they may be almost any age (range 23 to 81 years). ${ }^{1-18}$ Apart from the chronic watery diarrhoea, which may be present for weeks or many years, patients are remarkably well. ${ }^{12}$ No firm association has been made with any other medical condition, although polyarthritis or rheumatoid disease has featured in some reports. ${ }^{11} 1525$ Routine haematological and biochemical measurements are usually normal, microbiological investigations are negative, barium studies are generally unremarkable, and endoscopic abnormalities of the large bowel mucosa are nearly always unimpressive, even if present. The term collagenous colitis was originally chosen by Lindstrom by analogy with collagenous sprue, a lesion of the small intestine in which villous atrophy and a subepithelial collagen band are associated with malabsorption, ${ }^{27}$ but the two lesions are unrelated clinically and do not coexist. Collagenous colitis is confined to the colon and is usually diffuse, ${ }^{7323}$ albeit with some variation in the collagen thickness. Usually the change is apparent in a rectal biopsy, although not always. ${ }^{22}$

The course of the illness is variable: some patients have chronic persistent diarrhoea ${ }^{14}$; some have relapses and remissions ${ }^{10-13}$; and a few have apparent spontaneous resolution either with $^{78}$ or without ${ }^{1028}$ disappearance of the abnormal collagen band. Conventional medical treatment is usually ineffective, ${ }^{12}$ although there are reports of improvement with metronidazole, ${ }^{1129}$ mepacrine, ${ }^{4}$ prednisolone, ${ }^{10} 13$ sulphasalazine, ${ }^{2326}$ and loperamide ${ }^{11}$ and also with the homoeopathic remedy Natrum Mur. ${ }^{12}$ But even those people with persistent symptoms suffer little detriment to their general health. ${ }^{12}$

As chronic watery diarrhoea is common and the histological changes of collagenous colitis seem to be rare the relation between them must be questioned critically. Does the thickened collagenous band cause diarrhoea by forming a barrier to water absorption, as suggested by Lindstrom, ${ }^{1}$ or is it a consequence of the diarrhoea? Or do the collagenous band and diarrhoea coexist by chance? Two perfusion studies have supported Lindstrom's hypothesis by showing net secretion of sodium chloride and water into the colonic lumen, ${ }^{1830}$ but a third study gave conflicting results. ${ }^{15}$ That the thickened collagen plate is a mere consequence of diarrhoea is unlikely because it is not found in other diarrhoeas of known cause.

Some aspects of collagenous colitis make us sceptical of its clinical importance; sometimes the band is seen without the diarrhoea, ${ }^{22}$ and the band may persist after the symptoms have resolved..$^{128}$ Nor do the absence of a recognised aetiological agent, the widely variable clinical course, and the lack of a uniform response to many treatments support a specific disease process. Most published reports are of small numbers of cases with varied emphasis, and many contain conflicting findings. What is now needed is a coordinated effort to collect details of many carefully investigated patients. Meanwhile we conclude that while chronic watery diarrhoea and substantial thickening of the collagen plate undoubtedly coexist in some patients there is insufficient evidence to accept collagenous colitis as a disease entity. The onus remains on the protagonists of collagenous colitis to show that it is more than a histological change of questionable importance.

GERAINT T WILLIAMS Senior lecturer and honorary consultant pathologist

JoHN RHODES Consultant physician, department of gastroenterology

University Hospital of Wales, Cardiff CF4 4XW

1 Lindstrom CG. "Collagenous colitis" with watery diarrhoea: a new entity? Pathologia Europaea 1976;11:87-9.

2 Nielsen VT, Vetner M, Harslof E. Collagenous colitis. Histopathology 1980;4:83-6. 
3 Bogomoletz WV, Adnet JJ, Birembaut P, Feydy P, Dupont P. Collagenous colitis: an unrecognised entity. Gut 1980;21:164-8.

4 Pieterse A, Hecker R, Rowland R. Collagenous colitis: a distinctive and potentially reversible disorder. F Clin Pathol 1982;35:338-40.

5 van den Oord JJ, Geboes K, Desmet VJ. Collagenous colitis: an abnormal collagen table? Two new cases and review of the literature. Am $\mathcal{J}$ Gastroenterol 1982;77:377-81.

6 Bogomoletz WV. Collagenous colitis: a clinicopathological review. Survey of Digestive Diseases 1983;1:19-25.

7 Eaves ER, McIntyre RLE, Wallis PL, Korman MG. Collagenous colitis: a recently recognised reversible clinico-pathological entity. Aust NZ J Med 1983;13:630-1.

8 Debongnie JC, de Galocsy C, Caholessur MO, Haot J. Collagenous colitis: a transient condition? Dis Colon Rectum 1984;27:672-6.

9 Flejou JF, Grimaud JA, Molas G, Baviera E, Potet F. Collagenous colitis. Arch Pathol Lab Med 1984;108:977-81.

10 Teglbjaerg PS, Thaysen EH, Jensen HH. Development of collagenous colitis in sequential biopsy specimens. Gastroenterology 1984;87:703-9.

1 Fausa O, Foerster A, Hovig T. Collagenous colitis. A clinical, histological and ultrastructural study. Scand J Gastroenterol [Suppl] 1985;20:8-23.

12 Kingham JGC, Levison DA, Morson BC, Dawson AM. Collagenous colitis. Gut 1986;27:570-7.

13 Palmer KR, Berry H, Wheeler PJ, et al. Collagenous colitis-a relapsing and remitting disease. Gut 1986;27:578-80.

14 Hwang WS, Kelly JK, Shaffer EA, Hershfield NB. Collagenous colitis: a disease of pericryptal fibroblast sheath? I Pathol 1986;149:33-40.

15 Giardiello FM, Bayless TM, Jessurun J, Hamilton SR. Collagenous colitis: physiologic and pathologic studies. Gastroenterology 1985;88:1392.

16 Guarda LA, Nelson RS, Stroehlein JR, Korinek JF, Raymond AK. Collagenous colitis. Am f Clin Pathol 1983;80:503-7.

17 Teglbjaerg PS, Thaysen EH. Collagenous colitis: an ultrastructural study of a case. Gastroenterology 1982;82:561-3.

18 Loo FD, Wood CM, Soergel KH, Komorowski RA, Cheung H, Gay S, Gay RE. Abnormal collagen deposition and ion transport in collagenous colitis. Gastroenterology 1985;88:1481.

19 Pascal RR, Kaye GI, Lane N. Colonic pericryptal fibroblast sheath: replication, migration, and cytodifferentiation of a mesenchymal cell system in adult tissue. I. Autoradiographic studies of normal rabbit colon. Gastroenterology 1968;54:835-51.

20 Kaye GI, Lane N, Pascal RR. Colonic pericryptal fibroblast sheath: replication, migration, and cytodifferentiation of a mesenchymal cell system in adult tissue. II. Fine structural aspects of normal rabbit and human colon. Gastroenterology 1968;54:852-65.

21 Gledhill A, Cole FM. Significance of basement membrane thickening in the human colon. Gut 1984;25:1085-8.

22 Gardiner GW, Goldberg R, Currie D, Murray D. Colonic carcinoma associated with an abnormal collagen table. Cancer 1984;54:2973-7.

23 Weidner N, Smith J, Pattee B. Sulfasalazine in treatment of collagenous colitis. Am $\mathrm{J}$ Med 1984;77:162-6.

24 Foerster A, Fausa O. Collagenous colitis. Pathol Res Pract 1985;180:99-104.

25 Erlendsson J, Fenger C, Meinicke J. Arthritis and collagenous colitis. Scand J Rheumatol 1983;12:93-5.

26 Farah DA, Mills PR, Lee FD, McLay A, Russell RI. Collagenous colitis: possible response to sulfasalazine and local steroid therapy. Gastroenterology 1985;88:792-7.

27 Weinstein WM, Saunders DR, Tytgat GN, Rubin CE. Collagenous sprue-an unrecognized type of malabsorption. N Engl f Med 1970;283:1297-301.

28 Guller R, Anabitarte M. Die Kollagenkolitis. Schweiz Med Wochenschr 1981;111:1076-9.

28 Guller R, Anabitarte M. Die Kollagenkolitis. Schweiz Med Wochenschr 1981;111:1076-9. Mogensen
535-40.

30 Rask-Madsen J, Grove O, Hansen MGJ, Bukhave K, Scient C, Henrik-Nielsen R. Colonic transport of water and electrolytes in a patient with secretory diarrhoea due to collagenous colitis. Dig Dis Sci 1983;28:1141-6.

\section{Doctors' ignorance of statistics}

Many of us faced with someone who quotes statistics find it difficult to distinguish whether any consequent conclusion is correct or whether we have been bamboozled. If we do not understand the basics of statistics then we cannot question the statements and claims that are built on them. But the nature of medical science is to use an understanding of probability to interpret limited studies and thus move closer towards assertions of what might be "true" or "right." Yet, recent evidence suggests, ${ }^{2}$ many doctors know little about statistics.

Wulff and colleagues sent a questionnaire to 250 Danish doctors (of whom 148 replied) to assess their knowledge of elementary statistical expressions (standard deviation, standard error, $p<0.05, p>0.05$, and the correlation coefficient $r$ ). ${ }^{1}$ Although the study was itself imperfect (it had some ambiguous multiple choice questions and did not verify the answers against what statisticians might answer), it produced thought provoking evidence of ignorance. From nine multiple choice questions respondents produced a median correct response of 1.4 . The authors concluded: "The statistical knowledge of most doctors is so limited that they cannot be expected to draw the right conclusions from those statistical analyses which are found in medical journals." Note, however, even in this article critical of others' knowledge, the extrapolation from 148 replies to a statement about "most doctors"-an example of studying a sample and then drawing global conclusions.

Nevertheless, the Danish doctors who replied clearly knew little (and the 102 who did not reply may have known less). Are doctors in other countries more knowledgable? The evidence suggests not. Other studies have reported defects in statistical skills ${ }^{2}$ and shown that they become worse with increasing time from graduation. ${ }^{2}$ In one study the respondents showed a perceived need for other doctors to have a biostatistical training together with a lack of enthusiasm for their own education in the subject ${ }^{4}-\mathrm{a}$ dichotomy that has been noted before. ${ }^{5}$ But innumerate doctors cannot interpret scientific biological data ${ }^{6}$ They are doomed to have to accept without reservation the ștatements made in summaries, discussions, or conclusions, and their clinical practice may thus be altered on the basis of flimsy or inconclusive evidence.

In Britain the General Medical Council has since 1967 recommended that the medical curriculum should include teaching in statistics, ${ }^{7}$ and each medical student is now exposed to between 11 and 48 teaching hours (median 24) and most are examined in this knowledge. This teaching is reviewed at a workshop of statisticians held annually at the University of Bristol. ${ }^{8}$ But the problem remains that if interpreting statistics is not a regular activity the knowledge will evaporate. All doctors will have known the first and second laws of thermodynamics at some stage, but few could now recite or use them. Statistics cannot be understood in a vacuum: knowing that a correlation coefficient can vary between 0 and +1 (or 0 and -1 ) is of little value unless one understands its dependence on the number of observations. Similarly values become highly significant when the number of observations is large even when the correlation coefficient is very small.

There are a variety of approaches to the problem, which are not mutually exclusive. Medical students must continue to be taught the basic technicalities of statistics, and some comprehension of $p$ values, $r$ values, and confidence intervals should be instilled into all. But the teaching also needs to encompass a sense of what data mean. The need is to teach how to obtain information from data and knowledge from information. Journals need to ensure that results are explained in terms that the statistically amblyopic can still comprehend. Confidence intervals should be more widely used, ${ }^{10}$ and diagrams should be encouraged, especially where correlations are concerned. Expansive statements claiming "fact" from probability should be discouraged, and, despite the policy of some editors, all medical journals should allow space in their letter columns for disagreements and informed counter opinions.

DAVID R MATTHEWS Joan and Richard Doll senior research fellow

Green College,

Oxford, and

Honorary Consultant Physician,

Diabetes Research Laboratories,

Radcliffe Infirmary,

Oxford OX2 6HE

KLIM MCPHERSON University lecturer in medical statistics

Department of Community Medicine and

General Practice,

Radcliffe Infirmary,

Oxford OX2 6HE 